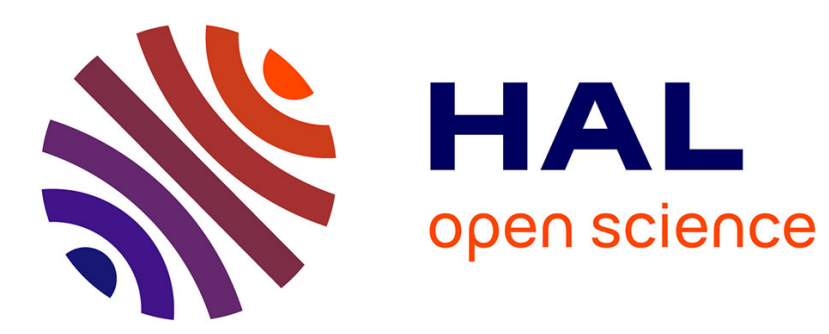

\title{
Fracture toughness of fine grained micro-alloyed steels at nil ductility temperature and transition range
}

\author{
J. Vojvodic-Gvardjancic, B. Ule, S. Azman
}

\section{To cite this version:}

J. Vojvodic-Gvardjancic, B. Ule, S. Azman. Fracture toughness of fine grained micro-alloyed steels at nil ductility temperature and transition range. Journal de Physique IV Proceedings, 1993, 03 (C7), pp.C7-105-C7-108. 10.1051/jp4:1993714 . jpa-00251760

\section{HAL Id: jpa-00251760 https://hal.science/jpa-00251760}

Submitted on 1 Jan 1993

HAL is a multi-disciplinary open access archive for the deposit and dissemination of scientific research documents, whether they are published or not. The documents may come from teaching and research institutions in France or abroad, or from public or private research centers.
L'archive ouverte pluridisciplinaire HAL, est destinée au dépôt et à la diffusion de documents scientifiques de niveau recherche, publiés ou non, émanant des établissements d'enseignement et de recherche français ou étrangers, des laboratoires publics ou privés. 


\title{
Fracture toughness of fine grained micro-alloyed steels at nil ductility temperature and transition range
}

\author{
J. VOJVODIČ-GVARDJANČIČ, B. ULE* and S. AŽMAN**
}

Institute for Metal Structures, Mencingerjeva 7, 61000 Ljubljana, Slovenia

* Institute of Metals and Technologies, Lepi pot 11, 61000 Ljubljana, Slovenia

** Steelwork Jesenice, Cesta Železarjev 8, 64270 Jesenice, Slovenia

The conventional test methods combined with non-standard measuring of fracture toughness $K_{\text {ic }}$ for the determination of low-temperature limit of exploitation was applied on nine different structural steels either fine-grained micro-alloyed steels or low-alloyed structural steels. These experiments confirmed that the results of low-temperature tests could be succesfully used for the calculation of some fracture mechanics characteristics of the investigated steels as for instance the dynamics yield strenght $\sigma_{y d}$, the dynamics fracture toughness $K_{i d}$ and, of course, the static fracture toughness $K_{i c}$.

The microalloying of steel is a technology which has been intensively developed for about 25 years. It exploits the theoretical knowledge on mechanisms of precipitation hardening, grain size control and deformation of steel. The term "microalloying" is used because steels are alloyed with up to $0.10 \%$ of various elements, and an important influence on the characteristics and properties of such steels is achieved, presumably due to the reduction of the austenite and ferite grain size and because their yield stress, strength and toughness are increased while the ductile/brittle transition temperature is diminished which is perhaps one of the most important aspect of microalloying.

The conventional test methods combined with non-standard measuring of fracture toughness $\mathrm{K}_{\mathrm{IC}}$ for the determination of low-temperature limit of exploitation was applied on nine different structural steels either fine-grained micro-alloyed steels or low-alloyed structural steels. The chemical composition of the investigated steels is shown in Table 1 and it can be seen that these steels with 0.05 to $0.21 \mathrm{wt}$. \% of carbon were alloyed with chromium, nickel, molibdenum, niobium or vanadium whether individually or in combination. The microstructure of such steels either hot-rolled and subsequently cooled with different cooling rates or thermomechanically treated was mainly ferritic with different shares of perlite or bainite. Only two types of low-alloyed steels have a microstructure of tempered martensite. The yield stress of investigated steels varied from $265 \mathrm{MPa}$ for plain carbon steel to $1000 \mathrm{MPa}$ for NIONICRAL $96 \mathrm{i}$.e. for submarine steel alloyed with chromium, nickel and molibdenum.

Examples of Charpy V-notch impact curves of absorbed energy versus testing temperature for investigated structural steels in as received condition i.e. either hot rolled and cooled with different cooling rates or thermomechanically treated are presented in Fig.2. The arrows indicate the nil-ductility temperatures determined at drop weight tests. The wide range of transition temperatures in this diagram clearly shows that wery different steels were used in our research. The relationship between Charpy-V notch energy and testing temperatures was also determined for aged steels, that is for steels which were cold-rolled with a reduction in thickness of $10 \%$ and additionally heated for 30 minutes at $250^{\circ} \mathrm{C}$. This relationship is shown in Fig. 3 from which it can be immediately concluded that aging provokes an expected and systematic shift of Charpy curves towards higher temperatures. However, it seems also that the nil ductility temperatures are decreased due to aging, which somewhat surprised. This general estimation incited us to make exact measurements of $\mathrm{K}_{\mathrm{IC}}$ values in the transition temperature region. 
Table 1 - Chemical composition of the steel (weight \%)

\begin{tabular}{|c|c|c|c|c|c|c|c|c|c|c|}
\hline $\begin{array}{l}\text { Vrsta jekla } \\
\text { Steel grade }\end{array}$ & C & $\mathrm{Si}$ & $\mathrm{Mn}$ & $\begin{array}{l}P \\
S\end{array}$ & $\mathrm{Cr}$ & $\mathrm{Ni}$ & Mo & $\mathrm{Ti}$ & Nb & $\mathrm{V}$ \\
\hline $\begin{array}{l}\text { NLOVAL } 47 \\
(20 \mathrm{~mm})\end{array}$ & 0.19 & 0.42 & 1.49 & $\begin{array}{l}0.013 \\
0.005\end{array}$ & 0.13 & 0.10 & 0.04 & 0.01 & 0.050 & 0.07 \\
\hline $\begin{array}{l}\text { NIOVAL } 47 \\
(65 \mathrm{~mm})\end{array}$ & 0.14 & 0.33 & 1.53 & $\begin{array}{l}0.014 \\
0.005\end{array}$ & 0.16 & 0.15 & 0.01 & 0.01 & 0.042 & 0.07 \\
\hline $\begin{array}{l}\text { NIONICRAL } 70 \\
(20 \mathrm{~mm})\end{array}$ & 0.11 & 0.28 & 0.27 & $\begin{array}{l}0.009 \\
0.007 \\
\end{array}$ & 1.07 & 2.80 & 0.26 & 0.01 & $\begin{array}{l}0.20 \\
\mathrm{Cu}\end{array}$ & 0.06 \\
\hline $\begin{array}{l}\text { NIONICRAL } 70 \\
(50 \mathrm{~mm})\end{array}$ & 0.11 & 0.37 & 0.34 & $\begin{array}{l}0.009 \\
0.003\end{array}$ & 1.03 & 2.63 & 0.27 & 0.01 & $\begin{array}{l}0.17 \\
\mathrm{Cu}\end{array}$ & 0.08 \\
\hline $\begin{array}{l}\text { NIONICRAL } 96 \\
(50 \mathrm{~mm})\end{array}$ & 0.14 & 0.29 & 0.51 & $\begin{array}{l}0.017 \\
0.009 \\
\end{array}$ & 1.64 & 2.76 & 0.42 & 0.01 & $\begin{array}{l}0.21 \\
\mathrm{Cu}\end{array}$ & 0.01 \\
\hline $\begin{array}{l}\text { NIOMOL } 490 \mathrm{~K} \\
(60 \mathrm{~mm})\end{array}$ & 0.05 & 0.35 & 0.42 & $\begin{array}{l}0.011 \\
0.004 \\
\end{array}$ & 0.75 & 0.29 & 0.33 & 0.01 & 0.058 & $\begin{array}{r}0.40 \\
\mathrm{Cu} \\
\end{array}$ \\
\hline $\begin{array}{l}\text { C..0562 } \\
(25 \mathrm{~mm}) \\
\end{array}$ & 0.17 & 0.32 & 1.28 & $\begin{array}{l}0.020 \\
0.009 \\
\end{array}$ & 0.21 & 0.23 & 0.05 & 0.01 & 0.003 & $\begin{array}{r}0.35 \\
\mathrm{Cu} \\
\end{array}$ \\
\hline $\begin{array}{l}\text { C̆.0562 } \\
(80 \mathrm{~mm})\end{array}$ & 0.18 & 0.46 & 1.29 & $\begin{array}{l}0.036 \\
0.004 \\
\end{array}$ & 0.30 & 0.15 & 0.03 & 0.01 & 0.001 & $\begin{array}{c}0.22 \\
\mathrm{Cu} \\
\end{array}$ \\
\hline $\begin{array}{l}\text { C.1204 } \\
(30 \mathrm{~mm})\end{array}$ & 0.21 & 0.25 & 0.51 & $\begin{array}{l}0.011 \\
0.025\end{array}$ & 0.02 & 0.04 & 0.01 & 0.01 & 0.050 & $\begin{array}{r}0.09 \\
\mathrm{Cu}\end{array}$ \\
\hline
\end{tabular}

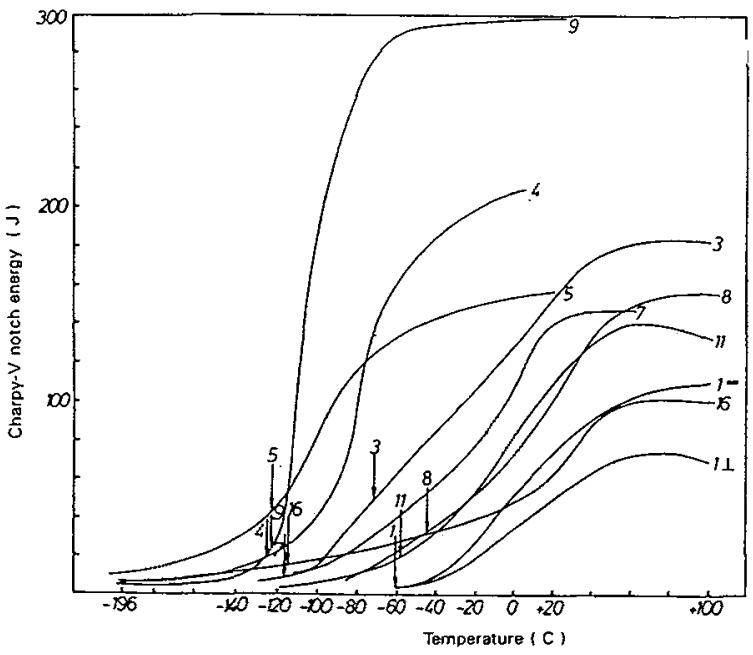

AS RECENVED

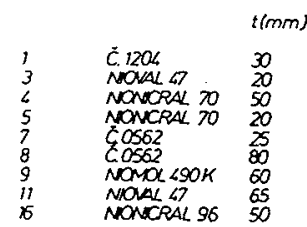

Fig 2 : Relation between Charpy- $V$ notch toughness and testing temperatures. The arrows indicate the nil-ductlity temperatures.

The fracture toughness measurements were made on cylindrical round-notched tension specimens with fatigue crack in the notch root. Such specimen is schematically shown in Fig.4. The $\mathrm{K}_{\mathrm{IC}}$ values were calculated in accordance with the well-known Heckel equation taking into consideration both limiting conditions. The virtual fracture load $\mathrm{P}^{*}$ was determined from load-displacement diagrams after taking into account the concept of equivalent energy, that is after the transformation of the surface under the parabolic curve into the quantitatively equal surface of the triangle. Therefore, the weak elasto-plastic fracture behaviour of the investigated steels in the vicinity of nil-ductility temperatures was approximated to a linear elastic fracture behaviour. The fracture surface of cylindrical round-notched tension specimens with circumferencial fatigue crack propagation area was observed with the SEM technique at small magnification. The fatigue crack propagation area was sharply separated from the circular central part of the fast fracture area so that the diameter (d) of this area could be easily measured. 


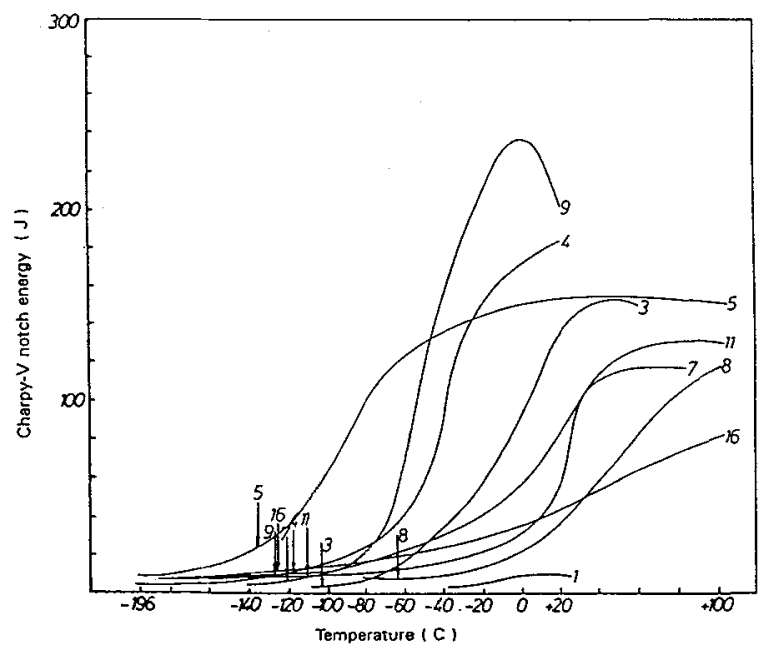

AGED

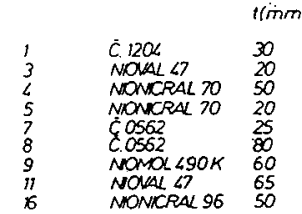

Fig 3 : Relation between Charpy-V notch toughness and testing temperatures. The arrows indicate the nil-ductlity temperatures.
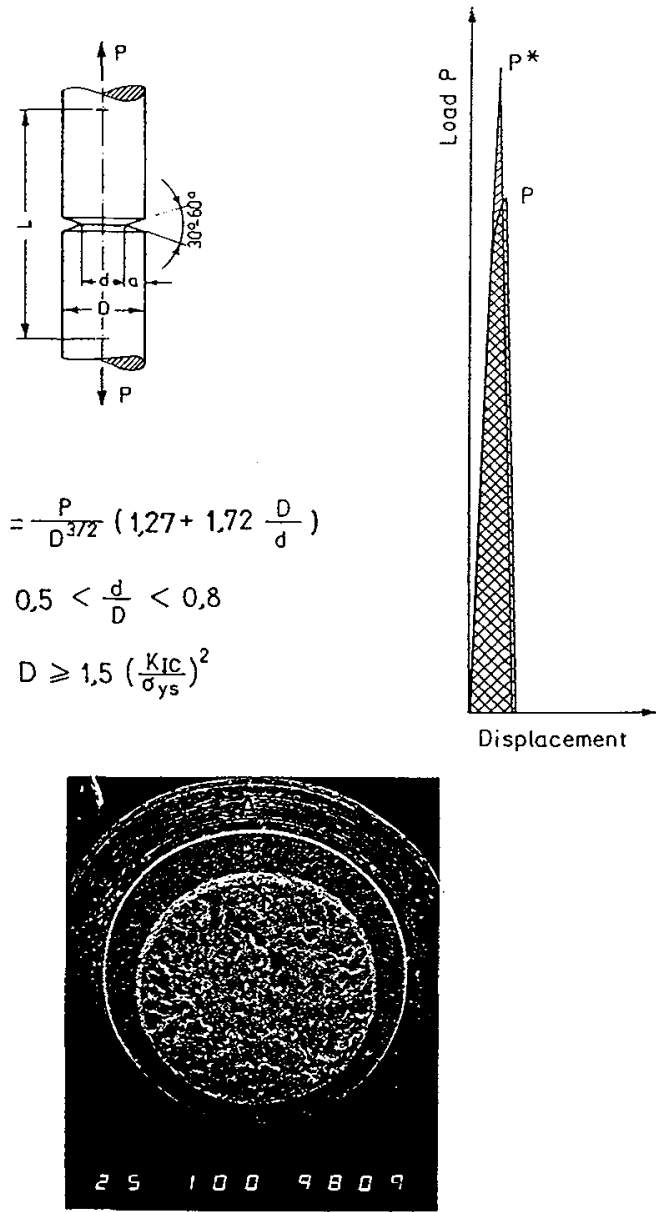

Fig 4 : Cylindrical round-notched tension specimens with fatigue crack in the notch rooth. 
To establish correlations between $\mathrm{K}_{\mathrm{IC}}$ and CVN test results in the transition-temperature range, the effect of both notch acuity and loading rate usually should be considered. But, as it is known that a particular change in loading rate causes an equal shift along the temperature axis for both the CVN data and the $K_{I C}$ data, Barsom and Rolfe succeeded to establish a correlation between the slow-bend $\mathrm{K}_{\mathrm{IC}}$ and the impact CVN test results in the transition temperature range. The results of our low-temperature measurements are shown in the diagram on Fig.5.
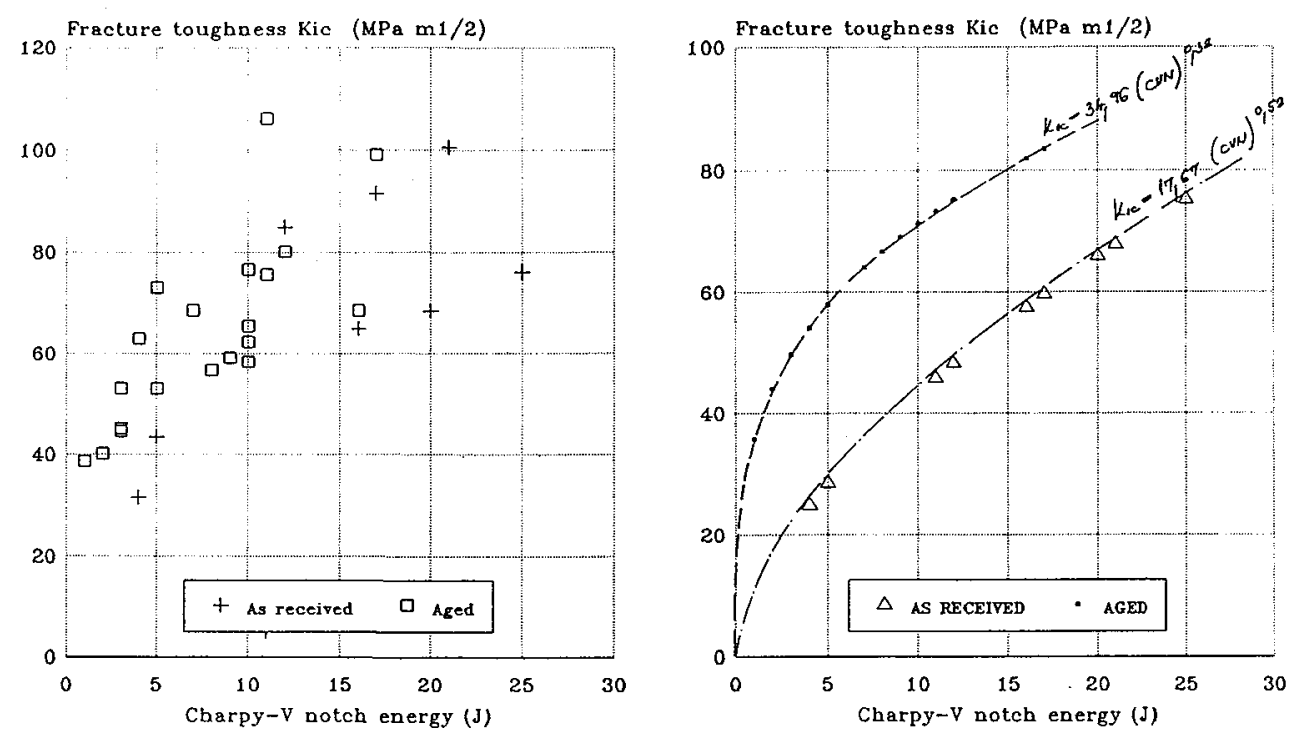

Fig $5: \mathrm{K}_{\mathrm{IC}} \mathrm{CVN}$ relationship in transition temperature range

Mechanical properties of the steel are shown in Table 2.

Table 2 : Mechanical properties of the steel

\begin{tabular}{|c|c|c|c|c|c|c|}
\hline $\begin{array}{l}\text { Vrsta jekla } \\
\text { Stcel grade }\end{array}$ & $\begin{array}{r}\sigma_{y y} \\
(\mathrm{MPa})\end{array}$ & $\begin{array}{r}T_{N D T} \\
\left({ }^{\circ} \mathrm{C}\right)\end{array}$ & $\begin{array}{r}\sigma_{\mathbf{y d}} \\
(\mathrm{MPa})\end{array}$ & $\begin{array}{l}T_{1 / 2} \\
\left({ }^{\circ} \mathrm{C}\right)\end{array}$ & $\begin{array}{r}K_{/ d} \\
\left(\mathrm{MPa} \cdot \mathrm{m}^{1 / 2}\right)\end{array}$ & $\begin{array}{l}T_{F T E} \\
\left.\text { ( }^{\circ} \mathrm{C}\right)\end{array}$ \\
\hline $\begin{array}{l}\text { NIOVAL } 47 \\
(20 \mathrm{~mm})\end{array}$ & 442 & .72 & 778 & -30 & 58 & .37 \\
\hline $\begin{array}{l}\text { NIOVAL } 47 \\
(65 \mathrm{~mm})\end{array}$ & 417 & -57 & 717 & -3 & 54 & .22 \\
\hline $\begin{array}{l}\text { NIONICRAL } 70 \\
(20 \mathrm{~mm})\end{array}$ & $\overline{737}$ & -123 & 1252 & -98 & 94 & .88 \\
\hline $\begin{array}{l}\text { NIONICRAL } 70 \\
(50 \mathrm{~mm})\end{array}$ & 726 & -124 & 1246 & -80 & 93 & -89 \\
\hline $\begin{array}{l}\text { NIONICRAL } 96 \\
(50 \mathrm{~mm})\end{array}$ & 1003 & -115 & 1483 & +10 & 111 & .80 \\
\hline $\begin{array}{l}\text { NIOMOL } 490 \mathrm{~K} \\
(60 \mathrm{~mm})\end{array}$ & 414 & -122 & 925 & .105 & 69 & .87 \\
\hline $\begin{array}{l}C .0562 \\
(25 \mathrm{~mm})\end{array}$ & 366 & -115 & 845 & -20 & 63 & .80 \\
\hline $\begin{array}{l}8.0562 \\
(80 \mathrm{~mm})\end{array}$ & 355 & -45 & 629 & +7 & 47 & .10 \\
\hline $\begin{array}{l}\bar{c} .1204 \\
(30 \mathrm{~mm})\end{array}$ & 265 & -60 & 572 & +4 & 43 & -25 \\
\hline
\end{tabular}

REFERENCES

I. OKAMOTO, S., TOYAMA, M., MOUE, T.; Transaciions ISIS, Vol.27, (1987), 474477.

2. MEKKAWY, M.F. EL-FAWAKHRY, K.A., MISHREKY, M.L., EISSA, M.M.; Scan-

dinavian Joumal of Metallurgy, 19, (1990), 246-256.

3. HALL, E.O.; Proc. Pays. Soc. Scrics B, 64, (1951), 747.

4. PETCH, NJ.: I. Iron Stocl In st., 174, (1953), 25.

5. OKUMURA. N.: Metal Science, Vol.17. (1983). 581-589.

6. CURRY, D.A., KNOT, J.F.; Mctal Science, (1978), 511-S14.

7. DAHL, W., HENGSTENBERG, H., BEHRENS, H.: Stall u. Eisen, 88, (1968), No.11, 578-596. 